

\title{
The decline of democracy in Bolivia and Brazil
}

Autor: Michael Chibba

DOI: https.:///oi.org/10.25058/1794600X.1801

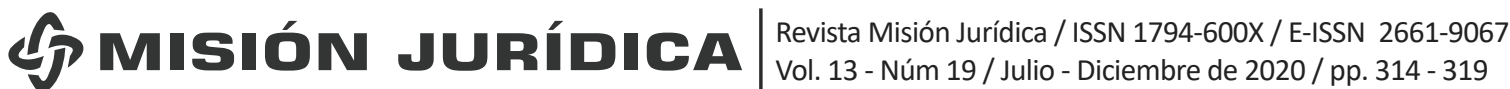




\section{THE DECLINE OF DEMOCRACY IN BOLIVIA AND BRAZIL*}



\section{Michael Chibba}

Democracy means freedom. There are many forms of freedom that are fundamental to democracy, such as the freedom to vote, the freedom of the press, the freedom of speech, the freedom to write and express one's opinions, the freedom to live where one chooses, the freedom of assembly, the freedom to strive for inclusiveness and equality, and other such fundamental freedoms. Moreover, there are numerous shades of democracy as not all such freedoms are present to the same degree in each and every democratic nation. To ensure democratic conduct, each country has rules and regulations to serve as a guide, as a set of dictums, to assist with law, order and justice, in the absence of which there is the prospect of either anarchy or authoritarianism.

Democracy is in retreat in the world, lament some academics (Chu, Huang, Lagos, and Mattes, 2020), who argue that decreasing support for democracy is tied to low levels of satisfaction in democracy by the populace, as well as to the rise of populist leaders who concentrate power in the executive branch. Not so in Latin America, where different dynamics are at play in democracy's decline: in Brazil under Bolsonaro, for example (Chibba, 2020a); and in Bolivia, post-Morales (Chibba, 2020b). Both of these cases will now be discussed.

\section{BOLIVIA}

\section{Colonialism and democracy}

Colonialism was the ideological and operational basis for the administration and governance of Bolivia since the early 1800s. The minority non-indigenous people subjugated the majority indigenous population for nearly two centuries. This left a profound legacy of neglect, poverty, abuse, suffering and injustices. 
Seismic changes came recently, beginning in 2005, when the iconoclastic Evo Morales, an ethnic Aymara, became the first indigenous person in history to become the President of Bolivia. Morales left his imprint as the national leader who introduced democracy to Bolivia. During his term in office, there was stability in an otherwise highly unstable country (as history provides ample evidence of this). In pursuing the tenets of democratic governance, Morales abandoned the colonial-type political economy and, in its stead, embraced the plurinational ideology (to reflect the "communal and social" diversity of Bolivia) and advanced a directly related development paradigm for the nation.

Bolivia's nascent but fragile democracy under Morales was path-breaking and it had a hugely positive impact on the country as, in many ways, the nation was transformed economically, politically, socially, and institutionally. This was in major departure from the long-standing status quo to governance and development as pursued by past governments. The indigenous people were no longer second-class citizens and played an active role in its democracy with equal rights, freedoms and benefits (social and economic).

\section{Coup d'etat}

However, in November 2019, with the withdrawal of support from both the armed forces and the police, the coup took place (for a detailed account, see Anderson, 2020). But it was neither a bloodless coup nor a non-violent one: several of Morales's supporters were killed; one pro-Morales mayor of a small city had her hair chopped and she was then doused in paint and paraded in public. There were many other similar incidents of violence against Morales's supporters perpetrated by those who led the coup. In addition, there were also threats against former senior officials of his government, some of whom sought refuge in a foreign embassy in La Paz.

Morales's departure brought an abrupt end to one of Latin America's most remarkable Presidencies. During his time in office, he transformed Bolivia, reducing poverty by roughly half, tripling its GDP, and reducing inequality substantially. Also, according to the World Bank (2020), Bolivia's GDP per capita (in constant U.S. dollars) increased steadily and sharply during his time in office, rising from $\$ 1,700$ in 2005 to $\$ 2,560$ in 2018. Democracy and plurinationalism worked in tandem to transform Bolivia under Morales.

\section{Political economy}

From a political economy perspective (Chibba and Luiz, 2019), there was convergence of key factors - namely, of government, ideology, business and leadership. For instance, general convergence between government and business, as well as between non-indigenous and indigenous populations, prevailed. To be sure, in the absence of convergence, his government would not have lasted as long as it did.

Whereas, divergence was the norm during the very long period of colonialism in the country when there was also an absence of democracy. Morales modernized the country by introducing social and economic programs to alleviate poverty and improve living standards. Those programs included a universal basic pension, a cash-transfer system, the distribution of packages of food, and the building of schools and hospitals. Moreover, Bolivia's comprehensive transformation impacted all aspects of democracy, political economy and society.

This was in contrast to the colonial policy that immiserated the indigenous populations over centuries, and ensured unequal access to justice, resources, economic opportunities, and basic rights. With Morales deposed, the present "interim" government of Jeanine Anez - installed by the military brass - finds its raison d'etre in a colonial-type form of governance, driven by an undemocratic and deeply flawed ideology that accepts divergence as the only real option for Bolivia. Importantly, divergence in Bolivia also means a return to two distinct societies within the nation, one indigenous and the other non-indigenous.

Moreover, under divergence, the future of the country is constrained by a dichotomy in the economic, political, social and ideological spheres. For divergence highlights polarized views, conflict, opposing interests, heightened discrimination and oppression, and lack of inclusiveness.

Morales's governance of Bolivia lasted fourteen years (as opposed to one year, on average, for all previous governments) due to four main reasons: first, he gave "voice" to and ensured 
inclusivity of the majority indigenous population; second, he introduced social and economic programs to benefit the poor, the disadvantaged, the marginalized, and the indigenous populace; third, development of the country focused on a comprehensive and plurinational strategy; fourth, he proved willing to work with the business sector, as long its members did not oppose him politically.

\section{Impact on democracy}

Programs and initiatives that benefit the poor, the indigenous, and the mestizo populations, will most likely be eliminated by the interim government as it is pursuing the pre-Morales form of governance, the status quo ante. For the majority of Bolivia's population, the coup signals a loss of democratic rights and freedoms, and a return to a modern form of colonialism, with its absence of broad-based economic, social, political and institutional benefits for the populace.

Does the coup mean the end of democracy in Bolivia? Probably not. But it is certainly an important harbinger of democracy's decline in Bolivia.

\section{BRAZIL}

\section{Democracy in Brazil}

It appears that Brazil's fledgling democracy is in peril of failing. Meanwhile, the nation faces a political economy (that is, by definition, interdisciplinary, and draws from economics, political science, law, and other social sciences) that is mired in illegal conduct at all levels, federal, regional and local. To better understand Brazil's predicament, it is important to remember that it was a colony of Portugal for over three centuries, when there was no democracy, until recently. And its political economy was colonial in nature. In 1985, an election ushered in civilian rule and thus began the expected democratization of the country, and with it a nascent and postcolonial political economy started to slowly take shape. Progress, however, has consistently been hampered by endemic corruption, a breakdown of law-and-order, the spread of the coronavirus, and the weaknesses of a fledgling democracy.
In January 2019, Jair Bolsonaro, a former military officer, was elected President on the promise of tackling law-and-order problems. He had campaigned on a fresh start that would purge corruption, crime and other illegal conduct. Instead, corruption and scandals have rocked his Presidency by implicating him, directly and indirectly, and his conduct is increasingly viewed as illegal. Exacerbating this situation is the comprehensive impact of the coronavirus on all aspects of life, governance and democracy in Brazil. This has prompted the nation's political economy to take shape in a manner that is exposing actions that are not founded on good governance but rather on shenanigans, political maneuvering, right-wing values (as was the case during colonial times), and the promotion of Bolsonaro's personal and ideological agendas.

\section{Stress points}

Meanwhile, the country's economy is in a tailspin because of the economic, social and political impacts of the coronavirus, which he has not handled well, dismissing it as nothing more than the common flu, and therefore not worthy of concern, even when deaths and cases of infection have mounted daily throughout the country.

Another concern is that, over the last three months, Bolsonaro's government has been rocked by the resignation of the highly-regarded Justice Minister Sergio Moro, who has implicated the President of wrongdoing in the firing of Mauricio Veleixo, the federal police chief - that is, the dismissal was without cause or justification. Also, it was overreaching by Bolsonaro as his decision was outside his designated area of responsibility (for the police chief is independent of the Presidency). Both Moro's resignation and Veleixo's firing were especially damning for Bolsonaro, who is currently being investigated for impeachable conduct in Veleixo's dismissal. In mid-April this year, Bolsonaro fired the Heath Minister for advocating social distancing policies to address the spread of the coronavirus. All three of these recent developments have undermined democratic principles and Brazil's young democracy is under attack by its own President. To make matters worse, all of the President's children are being investigated by the federal police for possible wrongdoing (including corrupt actions, such as money-laundering by one son, 
and spreading fake news attacking justices of the Supreme Court by two sons).

\section{Impact on development and political economy}

Furthermore, the economic, political, social and cultural impacts of Bolsonaro's extreme rightwing policies in the reckless development of the Amazon, especially with total disregard for the welfare and survival of indigenous populations, is worrisome and contrary to enlightened and democratic governance. His failure to address environmental concerns is also another serious concern. Bolsonaro's view of Brazil's political economy is shaped by his personal and political ambitions (especially, his goal of re-election in 2022) and his business agenda (e.g. restarting the economy prematurely and recklessly, tied to his designs for re-election). These developments, coupled with his values, dictate what political and economic policies are to be advanced. Indeed, Bolsonaro's response to the spread of the coronavirus, and his aggressive and fast-paced development of the Amazon at all costs, epitomize his policy stance, strategy and corresponding actions. Consequently, Brazil's political economy is actually exhibiting both weak convergence (in terms of the cornerstones that encompass leadership, government, ideology, and the business sector) and simultaneously, divergence - in terms of politics and economics being interdependent but separate.

As a result, the governance of Brazil is showing signs of a de facto return to a blatantly colonialtype political economy, especially where two separate nations, one largely "non-indigenous", and the other indigenous, are exposed. These developments also mean that Bolsonaro displays a façade where politics and economics are seemingly not dichotomous, though in reality dichotomy and divergence are the new norm. This situation bears some resemblance to the case of Bolivia where, as a result of its November 2019 military coup, a return to a colonial-era political economy is aggressively and rapidly taking hold.

\section{Governance at the local and regional levels}

To understand the nature of democracy and political economy at the local and regional levels, I turn to the case of Itaborai, an urban center with a population of a quarter of a million, located 30 miles east of Rio de Janeiro. Corruption casts a long shadow on that city and shapes its political economy.

Douglas and Valle (2019) have reported that militias, comprised of bands of rogue and off-duty police and security officers, starting operating in Itaborai as well as in Rio's impoverished western neighbourhoods a while back - " politicians either turned a blind eye or collaborated with the groups". The militias charge for a wide array of services, including security, cooking gas, internet access, and cable TV. They have also cornered the market in contraband tobacco and have forced vendors to sell it. These gangs are now active across Rio and fourteen other cities in the state, affecting the lives of millions of people. More generally, but importantly. Douglas and Valle state "Corruption exacts a punishing cost throughout Brazil. Graft consumes as much as 2.3 percent of gross domestic product... (and) we have systematic corruption on all levels. It is a practice that's deeply embedded in the country, and in public security, it is no different."

Compounding this undemocratic atmosphere is that there is dissention in certain political spheres as many state governors and city mayors do not endorse Bolsonaro's policies. Notwithstanding, when the governance apparatus, the supporting systems, and the policies and regulations foster deep-rooted corruption and crime at the local and regional levels, there is a profound failure in governance. Political economy has a reinforcing role to play at the various levels of governance (small urban area, rural area, city, region, and nation). Upholding and advancing the tenets of democracy is therefore a profound challenge in Brazil in more ways than one.

\section{Return to a colonial-type governance?}

Moreover, as the coronavirus is unleashing havoc on all fronts in the country, the dismal situation is prompting Bolsonaro to conduct his affairs in an undemocratic manner, with clear indications of his leaning towards a modern day but colonial-type political economy and governance. 


\section{Concluding remarks}

Democracy is in decline in parts of Latin America, and Bolivia and Brazil are two cases that aptly illustrate this. Political economy in those countries is also suffering because of democracy's failings. But, as both Bolivia and Brazil have relatively nascent democracies, the current setbacks will likely be short-lived.

\section{BIBLIOGRAFÍA}

- Anderson, Jon Lee (2020). "The Burnt Palace", The New Yorker, 23rd March.

- Chibba, Michael (2020a). "Political economy and democracy in Brazil under Bolsonaro", OpenDemocracy, 19th June.

- Chibba, Michael (2020b). Modern Political Economy and Colonialism: The case of Bolivia, World Economics, 21, 2. Forthcoming.

- Chibba, Michael and John M. Luiz, 2019. "Is the Business Environment a Matter of Political Economy and Convergence?"
World Economics, 20(3): 191-219.

- Chu, Yun-han, Huang, Kai-Ping, Lagos, Marta, and Robert Mattes (2020). "A Lost Decade for Third-Wave Democracies?" Journal of Democracy, 31, 2: 166-181.

- Douglas, Bruce and Sabrina Valle (2019). "Extortion is booming in Bolsonaro's Brazil", Bloomberg Businessweek, 29th April.

- World Bank (2020). Development Economics Data Group - for data on Bolivia and Brazil. www.worldbank.org 